\title{
Selection of Specialization Class Using Support Vector Machine Method in SMA Negeri 1 Ambon
}

\author{
Stevanny Tamaela1, Yopi Andry Lesnussa², Venn Yan Ishak Ilwaru3 \\ ${ }^{1}$ Mathematics Department, Pattimura University \\ Email: annytamaela@gmail.com,yopi_a_lesnussa@yahoo.com, \\ vennilwaru007@gmail.com
}

\begin{abstract}
The curriculum is a system or education plan that is made by a government to form the abilities and character of children based on a standard, one of its forms is the division of specialization classes at the senior high school level. The 2013 curriculum emphasizes that all students in Indonesia can practice their abilities based on their interests and talents, therefore students no longer choose majors but choose abilities (interests) they specialize in. This research uses the Support Vector Machine (SVM) method in the Decision Making System (DMS) of specialization classes at SMA Negeri 1 Ambon. Using the factors driving student acceptance and selection as input data, the SVM method is processed with MATLAB Software and produces a classification of interest class with an accuracy rate of $100 \%$.
\end{abstract}

Keywords: 2013 Curriculum; Classification; Support Vector Machine

\section{INTRODUCTION}

The curriculum is a plan about forming the abilities and character of children based on a standard [1], The 2013 curriculum is a curriculum that simplification [2] and thematic-integrative, adding rainy learning hours to encourage students or students, one of the forms is the division of specialization classes at the High School level (SMA)[3]. Specialization aims to provide opportunities for students to develop their interests in a group of subjects by their scientific interests in tertiary institutions [4] and developing their interest in a particular discipline or skill [5].

Decision Making System is the process of choosing between two or more alternative actions to achieve goals or objectives. Several studies have concluded that there are various decision-making methods can determine reliable results. In this case, the method to be applied is the Support Vector Machine (SVM) algorithm, the SVM method is a technique for making predictions, both in the case of classification and regression [6][7][8]. SVM was introduced by Boser, Guyon, Vanpik, dan first presented in 1992 [9][10] at the Annual Workshop on Computational Learning Theory. The basic concept of SVM is a harmonization of computation theories that have existed tens of years before, such as the Hyperplane margin introduced by Aronszajn in 1950 [11]. However, until 1992 there had never been an effort to assemble these components. The basic principle of SVM is linear classifier [12], and further developed to be able to work on non-linear problems by incorporating the concept of kernel tricks in high- 
dimensional space [13]. SVM is a classification method with a relatively fast computative time and several studies have shown that SVM is superior in classifying. In Addition, There is a research about the classification of acoustic events using SVM-based clustering schemes. Several Classifiers Based On Support Vector Machines (SVM) Are Developed Using Confusion Matrix Based Clustering Schemes To Deal With The MultiClass Problem [14][15]. The main purpose of SVM is to increase the speed of training and testing, meaning that SVM can be used for large data [16]. Support Vector Machine (SVM) is used along with continuous wavelet transform (CWT), an advanced signalprocessing tool, to analyze the frame vibrations during start-up [17].

\section{METHODS}

This type of research is a case study. Namely, the SVM method determines the choice of interest in tenth-grade students. The material used in this study is secondary data obtained from the Sekolah Menengah Atas (SMA) Negeri 1 Ambon. Secondary data taken from SMA Negeri 1 Ambon is in the form of a value criterion as a measure of interest selection include the initial test scores in SMA 1 or a comparison score to determine the choice of interest in tenth-grade students.

In detail, the flowchart diagram of the Support Vector Machine (SVM) can be seen in the following Figure 1:

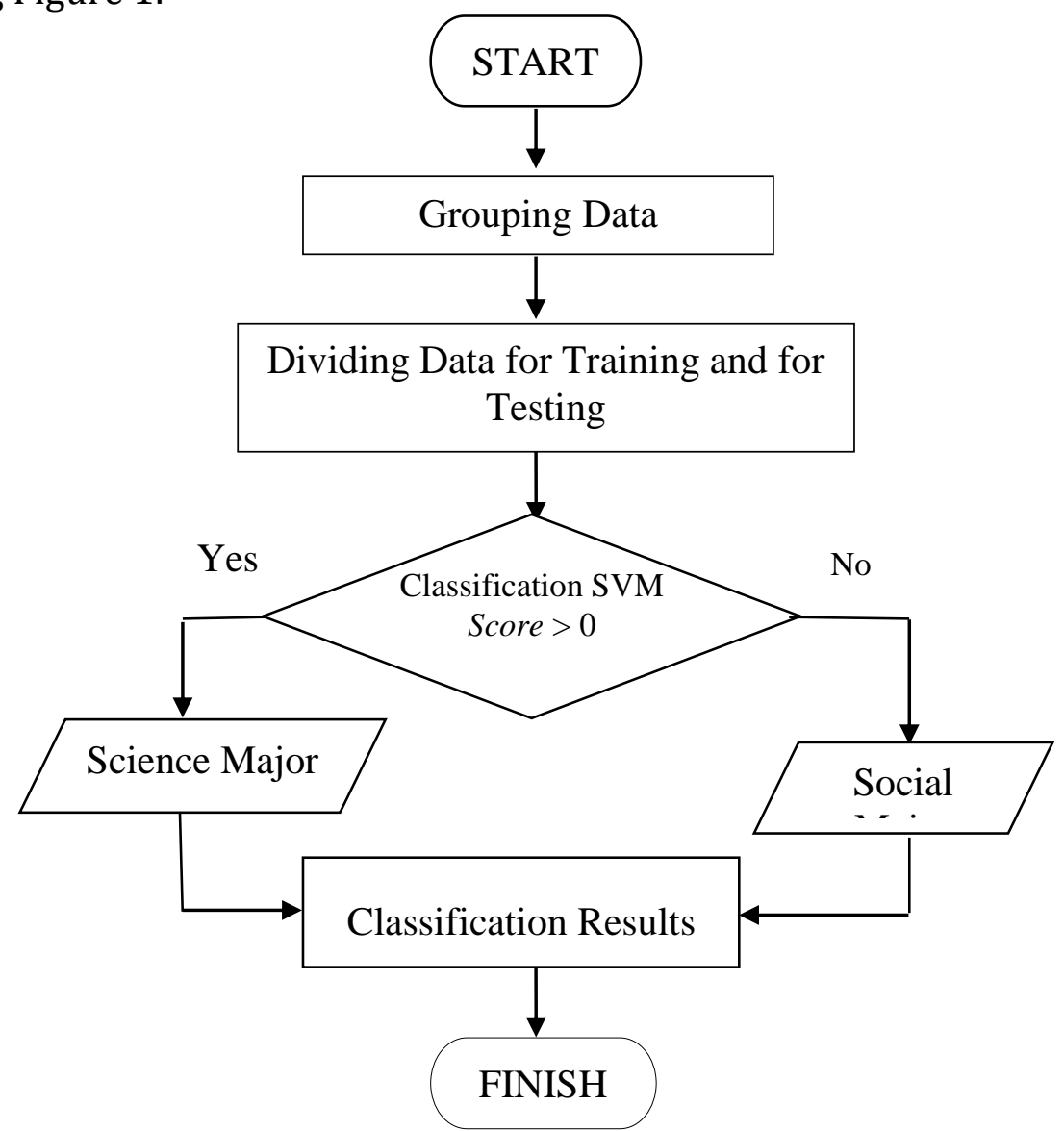

Figure 1. Flowchart Diagram of Support Vector Machine (SVM)

This research uses the linear SVM method with MATLAB software to analyze data. The Ratio of training and testing data used is 7:3 from each grouping that has been determined. 
For this research method the variables used for data are the National Exam Score $\left(X_{1}\right)$, Initial Test Score $\left(X_{2}\right)$, Psychology Score $\left(X_{3}\right)$. While the target or output is Major/ Interest $(Y)$. Data obtained as follows:

Table 1. SVM Method Data

\begin{tabular}{|c|c|c|c|c|c|}
\hline NO & $\begin{array}{c}\text { NATIONAL } \\
\text { EXAM } \\
\text { SCORE } \\
\text { (REC) }\end{array}$ & $\begin{array}{c}\text { INITIAL } \\
\text { TEST } \\
\text { SCORE }\end{array}$ & $\begin{array}{c}\text { PSYCHOLOGY } \\
\text { SCORE }\end{array}$ & $\begin{array}{l}\text { FINAL } \\
\text { SCORE }\end{array}$ & $\begin{array}{l}\text { MAJOR/ } \\
\text { INTEREST }\end{array}$ \\
\hline 1 & 82 & 35 & 106.7 & 74.57 & SCIENCE \\
\hline 2 & 80.2 & 34 & 86.2 & 66.8 & SOCIAL \\
\hline 3 & 80 & 34 & 100 & 71.33 & SCIENCE \\
\hline 4 & 81.5 & 34 & 94.4 & 69.97 & SOCIAL \\
\hline 5 & 80 & 34 & 93.9 & 69.30 & SOCIAL \\
\hline 6 & 85.5 & 33 & 111.8 & 76.77 & SCIENCE \\
\hline 7 & 84.5 & 33 & 111.9 & 76.47 & SCIENCE \\
\hline 8 & 80 & 33 & 86.1 & 66.37 & SOCIAL \\
\hline 9 & 81.5 & 33 & 109.6 & 74.70 & SCIENCE \\
\hline 10 & 80.8 & 32 & 106.3 & 73.03 & SCIENCE \\
\hline 11 & 80 & 32 & 97 & 69.67 & SOCIAL \\
\hline 12 & 83 & 32 & 106.7 & 73.90 & SCIENCE \\
\hline 13 & 82.5 & 32 & 92.6 & 69.03 & SOCIAL \\
\hline 14 & 81.9 & 31 & 107.7 & 73.53 & SCIENCE \\
\hline 15 & 80.5 & 31 & 92.6 & 68.03 & SOCIAL \\
\hline 16 & 80 & 31 & 98.7 & 69.90 & SOCIAL \\
\hline 17 & 81.5 & 31 & 83.3 & 65.27 & SOCIAL \\
\hline 18 & 80 & 31 & 91.3 & 67.43 & SOCIAL \\
\hline 19 & 85.5 & 30 & 90.6 & 68.70 & SOCIAL \\
\hline 20 & 84.5 & 30 & 101.3 & 71.93 & SCIENCE \\
\hline 21 & 80 & 30 & 89.7 & 66.57 & SOCIAL \\
\hline 22 & 80 & 30 & 93.6 & 67.87 & SOCIAL \\
\hline 23 & 83 & 30 & 88.3 & 67.10 & SOCIAL \\
\hline 24 & 82.5 & 30 & 111.4 & 74.63 & SCIENCE \\
\hline 25 & 81.9 & 30 & 97.7 & 69.87 & SOCIAL \\
\hline 26 & 80.5 & 30 & 109.6 & 73.37 & SCIENCE \\
\hline 27 & 80 & 30 & 104.5 & 71.50 & SCIENCE \\
\hline 28 & 81.5 & 30 & 100 & 70.50 & SCIENCE \\
\hline 29 & 83 & 30 & 91.1 & 68.03 & SOCIAL \\
\hline 30 & 82.5 & 30 & 103.9 & 72.13 & SCIENCE \\
\hline 31 & 81.9 & 30 & 100 & 70.63 & SCIENCE \\
\hline 32 & 80.5 & 28 & 104.2 & 70.90 & SCIENCE \\
\hline 33 & 83.9 & 28 & 106 & 72.63 & SCIENCE \\
\hline 34 & 84 & 28 & 92.9 & 68.30 & SOCIAL \\
\hline 35 & 80.5 & 28 & 87.7 & 65.40 & SOCIAL \\
\hline 36 & 80.4 & 28 & 86.9 & 65.10 & SOCIAL \\
\hline 37 & 81.3 & 28 & 111.9 & 73.73 & SCIENCE \\
\hline
\end{tabular}




\begin{tabular}{cccccc}
\hline NO & $\begin{array}{c}\text { NATIONAL } \\
\text { EXAM } \\
\text { SCORE } \\
\text { (REC) }\end{array}$ & $\begin{array}{c}\text { INITIAL } \\
\text { TEST } \\
\text { SCORE }\end{array}$ & $\begin{array}{c}\text { PSYCHOLOGY } \\
\text { SCORE }\end{array}$ & $\begin{array}{c}\text { FINAL } \\
\text { SCORE }\end{array}$ & $\begin{array}{c}\text { MAJOR/ } \\
\text { INTEREST }\end{array}$ \\
\hline 38 & 81.9 & 28 & 92.5 & 67.47 & SOCIAL \\
\hline 39 & 81 & 28 & 86.8 & 65.27 & SOCIAL \\
\hline 40 & 80.2 & 28 & 105 & 71.07 & SCIENCE \\
\hline 41 & 82 & 27 & 109.9 & 72.97 & SCIENCE \\
\hline 42 & 83.6 & 27 & 110.5 & 73.70 & SCIENCE \\
\hline 43 & 80 & 27 & 93.8 & 66.93 & SOCIAL \\
\hline 44 & 82.5 & 27 & 94.9 & 68.13 & SOCIAL \\
\hline 45 & 81.6 & 27 & 91.3 & 66.63 & SOCIAL \\
\hline 46 & 85 & 27 & 106.6 & 72.87 & SCIENCE \\
\hline 47 & 82.9 & 27 & 106 & 71.97 & SCIENCE \\
\hline 48 & 83.5 & 27 & 94.7 & 68.40 & SOCIAL \\
\hline 49 & 80 & 27 & 93.3 & 66.77 & SOCIAL \\
\hline 50 & 80 & 27 & 111.1 & 72.70 & SCIENCE \\
\hline
\end{tabular}

The amount of data in this study amounted to 50 data that will be divided into data testing and training. The target data of the Department is divided into 3 groups with the following conditions:

Science Major for $y>80$ with the very smart requirement

Neutral Major for $70 \leq \mathrm{y} \leq 80$ with the average requirement

Social Major for $\mathrm{y}<70$

Hint: $\mathrm{y}=$ Major

\section{RESULTS AND DISCUSSION}

SVM linear search for hyperplane with the largest margin, known as Maximum Marginal Hyperplane (MMH). Based on the Lagrangian formulation mentioned, $\mathrm{MMH}$ can be rewritten as a boundary decision:

$$
d\left(X^{T}\right)=\sum_{i=1}^{l} y_{i} \alpha_{i} X_{i} X^{T}+b_{0}
$$

Where $y_{i}$ is the label of support vector classes $X_{i} . X^{T}$ is the tuple; $\alpha_{i}$ and $b_{0}$ are the numerical parameter determined automatically by the SVM optimization algorithm, and $\mathrm{l}$ is the number of Support Vector. The results of the program for the grouping of testing data are as follows:

Table 2. Software Processing Results for Testing Data

\begin{tabular}{cccccc}
\hline No & $\begin{array}{c}\text { Original } \\
\text { Data }\end{array}$ & svmStruct1 & svmStruct2 & svmStruct3 & $\begin{array}{c}\text { Software } \\
\text { Results }\end{array}$ \\
\hline 1 & 0 & 0 & 0 & 0 & 0 \\
\hline 2 & 0 & 1 & 0 & 0 & 0 \\
\hline 3 & 0 & 1 & 0 & 0 & 0 \\
\hline 4 & 0 & 0 & 0 & 0 & 0 \\
\hline 5 & 0 & 0 & 0 & 0 & 0 \\
\hline 6 & 0 & 0 & 0 & 0 & 0 \\
\hline 7 & 0 & 0 & 0 & 0 & 0 \\
\hline 8 & 0 & 1 & 0 & 0 & 0 \\
\hline
\end{tabular}




\begin{tabular}{cccccc}
\hline No & $\begin{array}{c}\text { Original } \\
\text { Data }\end{array}$ & svmStruct1 & svmStruct2 & svmStruct3 & $\begin{array}{c}\text { Software } \\
\text { Results }\end{array}$ \\
\hline 9 & 1 & 1 & 1 & 1 & 1 \\
\hline 10 & 1 & 1 & 1 & 1 & 1 \\
\hline 11 & 1 & 1 & 1 & 1 & 1 \\
\hline 12 & 1 & 1 & 1 & 1 & 1 \\
\hline 13 & 1 & 0 & 1 & 1 & 1 \\
\hline 14 & 1 & 1 & 1 & 1 & 1 \\
\hline 15 & 1 & 0 & 1 & 1 & 1 \\
\hline 16 & 1 & 1 & 1 & 1 & 1 \\
\hline
\end{tabular}

From Table 2 above it can be seen, the SVM method classification shows the output with 99\% accuracy for testing data. This can be seen from the comparison between the target data and the output target. With Hyperplane obtained from each class as follows:

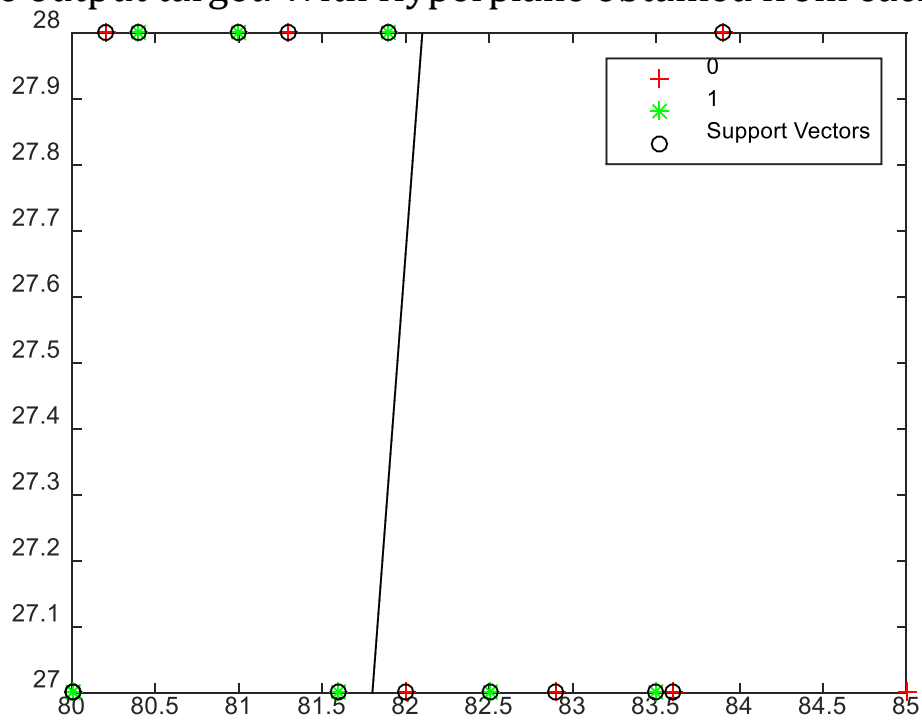

Figure 2. Hyperplane for svmStruct1

Based on Figure 2 above it can be explained that the svmStruct1 data shows that the data in the two classes are not completely separate can be seen from several red circles whose distribution is around the green circle area.

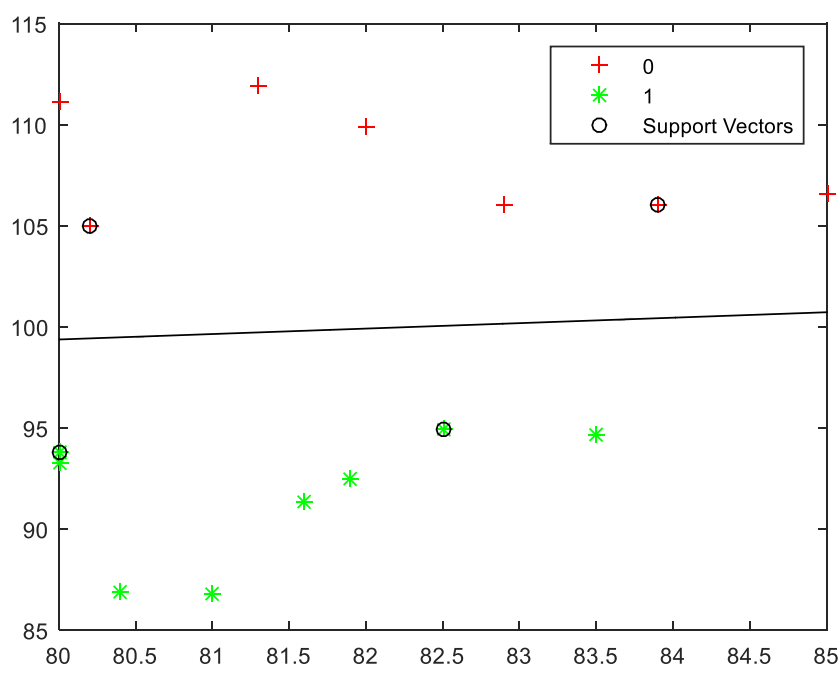

Figure 3. Hyperplane for svmStruct2 
Based on Figure 3 above it can be explained that the data in svmStruct 2 is properly classified in class 0 (which is the science major group) or class 1 (which is the social major group) while those that are Support Vector are patterns within a circle.

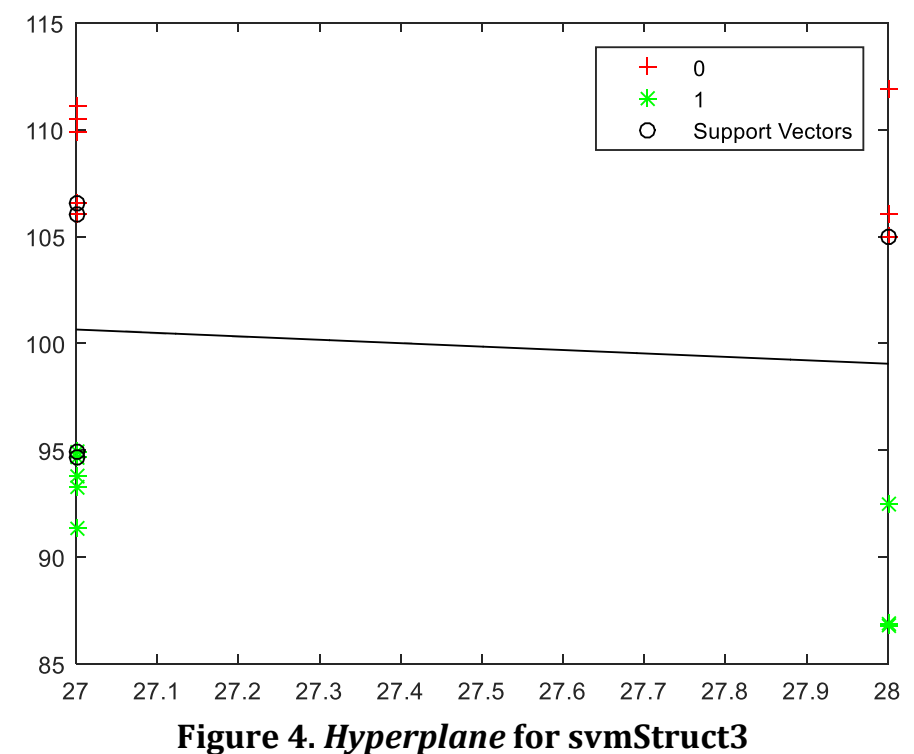

Based on Figure 4 above it can be explained that all svmStruct3 data is properly classified into class 0 (which is the science major) or class 1 (which is the social major), while those that are Support Vector are patterns within a circle.

\section{CONCLUSIONS}

From the results of the software output that is matched with the real data, it is seen that $100 \%$ of the output data is the same as the real data. This shows for the SVM method of class division of interests carried out by the school according to the ability of children. Based on the results of research with the SVM method there is no difference between the results of the assessment using software and real data. In other words the results of the SVM method are said to be perfect.

\section{REFERENCES}

[1] M. Lestari, "Implementation of Citizenship Character Formation by the Study of Civic Education on Senior High School in The District of Bantul," E-CIVICS, 2016.

[2] Suyatmini, "Implementasi Kurikulum 2013 pada Pelaksanaan Pembelajaran Akuntansi di Sekolah Menengah Kejuruan," J. Pendidik. Ilmu Sos., 2017.

[3] Subandi, "Pengembangan Kurikulum 2013," J. Pendidik. dan Pembelajaran Dasar, 2014.

[4] B. L. Julien, L. Lexis, J. Schuijers, T. Samiric, and S. McDonald, "Using capstones to develop research skills and graduate capabilities: A case study from physiology," $J$. Univ. Teach. Learn. Pract., 2012.

[5] Direktorat Pembinaan SMA, Modul Pelatihan Implementasi Kurikulum 2013 SMA Tahun 2018. 2018.

[6] A. S. Nugroho, A. B. Witarto, and D. Handoko, "Application of Support Vector Machine in Bioinformatics," 2003.

[7] A. M. Puspitasari, D. E. Ratnawati, and A. W. Widodo, "Klasifikasi Penyakit Gigi Dan Mulut Menggunakan Metode Support Vector Machine," J. Pengemb. Teknol. Inf. dan 
Ilmu Komput., vol. 2, no. 2, pp. 802-810, 2018.

[8] P. A. Octaviani, Yuciana Wilandari, and D. Ispriyanti, "Penerapan Metode Klasifikasi Support Vector Machine (SVM) pada Data Akreditasi Sekolah Dasar (SD) di Kabupaten Magelang," J. Gaussian, vol. 3, no. 8, pp. 811-820, 2014, [Online].

Available:http://download.portalgaruda.org/article.php?article=286497\&val=47 06\&title=Penerapan Metode Klasifikasi Support Vector Machine (Svm) Pada Data Akreditasi Sekolah Dasar (Sd) Di Kabupaten Magelang.

[9] Y. Lin, H. Tseng, and C. Fuh, "Using Support Vector Machine," Image Process., 2003.

[10] M. Ichwan, I. A. Dewi, and Z. M. S, "Klasifikasi Support Vector Machine (SVM) Untuk Menentukan TingkatKemanisan Mangga Berdasarkan Fitur Warna," MIND J., vol. 3, no. 2, pp. 16-23, 2019, doi: 10.26760/mindjournal.v3i2.16-23.

[11] Y. Wang, J. Wong, and A. Miner, "Anomaly intrusion detection using one class SVM," 2004, doi: 10.1109/iaw.2004.1437839.

[12] M. A. Oskoei and H. Hu, "Support vector machine-based classification scheme for myoelectric control applied to upper limb," IEEE Trans. Biomed. Eng., 2008, doi: 10.1109/TBME.2008.919734.

[13] S. Vijayakumar and S. Wu, "Sequential Support Vector Classifiers and Regression," 1999.

[14] S. Aprilia, M. T. Furqon, and M. A. Fauzi, "Klasifikasi Penyakit Skizofrenia dan Episode Depresi pada Gangguan Kejiwaan dengan Menggunakan Metode Support Vector Machine (SVM)," J. Pengemb. Teknol. Inf. dan Ilmu Komput., vol. 2, no. 11, pp. 5611-5618, 2018.

[15] A. Temko and C. Nadeu, "Classification of acoustic events using SVM-based clustering schemes," Pattern Recognit., vol. 39, no. 4, pp. 682-694, 2006, doi: 10.1016/j.patcog.2005.11.005.

[16] H. Amalia, A. F. Lestari, and A. Puspita, "Penerapan Metode SVM Berbasis PSO Untuk Penentuan Kebangkrutan Perusahaan," None, 2017.

[17] P. Dhanalakshmi, S. Palanivel, and V. Ramalingam, "Classification of audio signals using SVM and RBFNN," Expert Syst. Appl., vol. 36, no. 3 PART 2, pp. 6069-6075, 2009, doi: 10.1016/j.eswa.2008.06.126. 